\title{
Service Quality Model, Organizational Commitment, and TQM-based Education Leadership in Organizational Development
}

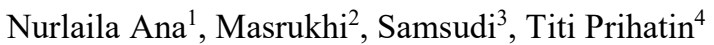 \\ \{lailaanafa@gmail.com¹, masrukhi@mail.unnes.ac.id ${ }^{2}$, samsudi@mail.unnes.ac.id², \\ titiprihatin@mail.unnes.ac.id $\left.{ }^{4}\right\}$ \\ SMP Negeri 8 Pekalongan, Jawa Tengah, Indonesia ${ }^{1}$, Graduate School Universitas Negeri Semarang, \\ Indonesia ${ }^{2,3,4}$
}

\begin{abstract}
This study aims to analyze the model of service quality, organizational commitment, and education leadership based on total quality management in organizational development. The benefits of the study were able to enrich the treasures of education management theory related to organizational development in educational institutions, especially junior high schools (SMP) in Pekalongan. The research design uses a quantitative positivistic approach with a structural equation (Structural Equation Model), with the model Second Order Confirmatory Factor Analysis. The research population of SMP teachers, while the sampling techniques are using proportionate stratified random sampling. The results of the study show that the development of school organizations is influenced significantly by the factors of service quality, organizational commitment, and education leadership based on Total Quality Management (TQM). This TQM is evidenced by the significance of the relationship of each independent variable to the dependent variable.
\end{abstract}

Keywords: TQM, Educational Leadership, Organizational Development

\section{Introduction}

Education in the world is experiencing rapid progress, there are developing countries such as Indonesia and Thailand are countries that are trying to improve the quality of education. Education in school is the beginning of the progress of the education sector of a country so it needs quality assurance to achieve long-term goals as an expression of TQM [1]. School managers must prepare well with innovation and strategies to improve school success [2].

Management integrated quality in education prioritizes achievement of expectations customers through continuous improvement efforts to find best practices [3]. The results of study, the higher the quality of service and school image, the greater satisfaction and loyalty [4]. The results of study that organizational commitment positively and significantly affects TQM [5].

The results of study that service quality has a causality relationship with organizational development [6]. Analyzing organizational culture has a positive and significant effect on the development of maritime organizations in Thai naval academies [7]. Organizational commitment has been proven to mediate the influence of organizational support and justice on the behavior of organizational citizenship [8]. 
Leadership is an essential component in the process of organizational commitment, leadership is critical for organizational effectiveness, and the development and change of corporate culture [9]. There was a significant effect of the principal's leadership, organizational culture and TQM implementation on the quality of the SMP in Pemalang Indonesia [10]. Leadership behavior can influence organizational commitment [11].

This study aims to analyze the influence of service quality, organizational culture, organizational commitment and leadership of TQM-based Education in the development of junior high school organizations in Pekalongan. The benefits of research as a study of the development of new theories about the development of junior high school organizations in Pekalongan are effective in carrying out their vision as a center of excellent junior secondary education institutions in Indonesia.

\section{Method}

This Study is using positive quantitative research method with structural equation models (Structural Equation Model), through the model approach Second Order Confirmatory Factor Analysis, the analysis tool used by LISREL (Linear Structural Relationship) is the analysis of multiple regressions. Analysis of this research data is multivariate analysis. Data analysis techniques were carried out using computers through Structural Equation Modeling (SEM) with the AMOS version 22.0 program.

The population of this study was all junior high school teachers who were civil servants and those who were not public servants in Pekalongan, which numbered 765 people. The total sample through the process screening and trimming was 244 samples, described in table 1 below:

Table 1. Description of Respondents by Category Age and Status (PNS and GTT /GTY)

\begin{tabular}{ccccccc}
\hline \multirow{2}{*}{$\begin{array}{c}\text { Age } \\
\text { (years) }\end{array}$} & \multicolumn{4}{c}{ Status } & \multicolumn{2}{c}{ Total } \\
\cline { 2 - 6 } & \multicolumn{2}{c}{ PNS } & \multicolumn{3}{c}{ GTT / GTY } & \multicolumn{2}{c}{} \\
\hline & $\Sigma$ & $\%$ & $\Sigma$ & $\%$ & $\Sigma$ & $\%$ \\
\hline$\leq 30$ & 5 & 2.05 & 2 & 0.82 & 7 & 2.87 \\
$31-35$ & 15 & 6.15 & 3 & 1.23 & 18 & 7.38 \\
$36-40$ & 48 & 19.7 & 9 & 3.69 & 57 & 23.4 \\
$41-45$ & 68 & 27.9 & 13 & 5.33 & 81 & 33.2 \\
$46-50$ & 29 & 11.9 & 14 & 5.74 & 43 & 17.6 \\
$>50$ & 24 & 9.84 & 14 & 5.74 & 38 & 15.6 \\
\hline & 189 & 77.5 & 55 & 22.5 & 244 & 100 \\
\hline
\end{tabular}

\section{Results and Discussion}

Index number variable service quality 71.23 (moderate); organizational commitment 73.93 (high); education leadership 60.84 (moderate); TQM (60.51); and organizational development 63.16 (medium).

The test results for the validity of all value indicators factor loading above 0.40 . All valid indicators have met the criteria convergent validity. Also, all the signs are reliable. Reliability with the Cronbach Alpha coefficient. The reliability test results for all indicators have Cronbach Alpha values above 0.60 . Results of convergent validity can be shown in table. 2 . 
Table 2. Results of Convergent Validity Testing with AMOS and SPSS

\begin{tabular}{|c|c|c|c|c|c|}
\hline & Variable & Indicator & $\begin{array}{c}\text { Corrected } \\
\text { Item-Total } \\
\text { Correlation } \\
\end{array}$ & $\begin{array}{l}\text { Cronbach } \\
\text { Alpha }\end{array}$ & shortages of \\
\hline \multirow[t]{5}{*}{1.} & Services Quality & Tangible & 0.718 & \multirow{5}{*}{0.846} & valid and \\
\hline & $(\mathrm{SQ})$ & Reliability & 0.686 & & Reliable \\
\hline & & Responsiveness & 0.741 & & \\
\hline & & Assurance & 0.763 & & \\
\hline & & Empathy & 0.709 & & \\
\hline \multirow[t]{3}{*}{2.} & Organizational & Affective commitment & 0.729 & \multirow{3}{*}{0.805} & valid and \\
\hline & Commitment & continuance commitment & 0.773 & & Reliable \\
\hline & $(\mathrm{OC})$ & Normative commitment & 0.787 & & \\
\hline \multirow[t]{4}{*}{3.} & Education & Vision Integrated Quality & 0.710 & \multirow{4}{*}{0.786} & valid and \\
\hline & Leadership (EL) & Message Quality & 0.612 & & Reliable \\
\hline & & Leading Innovation & 0.753 & & \\
\hline & & Team Building & 0.702 & & \\
\hline \multirow[t]{3}{*}{4.} & TQM & Total Quality & 0.854 & \multirow{3}{*}{0.851} & Valid and \\
\hline & & Customer Satisfaction & 0.774 & & Reliable \\
\hline & & Continuous Improvement & 0.804 & & \\
\hline \multirow[t]{6}{*}{5.} & Organizational & External Environment & 0.716 & \multirow{6}{*}{0.832} & \multirow{6}{*}{$\begin{array}{l}\text { Valid and } \\
\text { Reliable }\end{array}$} \\
\hline & \multirow{5}{*}{$\begin{array}{l}\text { Development } \\
\text { (OD) }\end{array}$} & Internal Environment & 0.722 & & \\
\hline & & $\begin{array}{l}\text { Organizational } \\
\text { effectiveness }\end{array}$ & 0.778 & & \\
\hline & & Employee welfare & 0.763 & & \\
\hline & & & Trafficking & & \\
\hline & & & Variance & & \\
\hline
\end{tabular}

Table 2 shows Value extracted service quality 0.724 ; organizational commitment 0.763 ; educational leadership 0.696 . The value of TQM variance extracted 0.811 and organizational development 0.745 . The value of exogenous and endogenous variance extracted constructs has a high value that is above the cut-off value of 0.50 . Value construct reliability service quality, organizational commitment, and educational leadership have high-reliability values which are above the cut-off value of 0.70 . TQM and organizational development are also above 0.7 . Variance extracted and construct reliability of indicators of exogenous and endogenous construct valid and reliable, shown in table. 3 .

Table 3. Calculation Square Root of AVE Constructs Exogenous Variables and Value Correlation Exogenous Variables

\begin{tabular}{clcccc}
\hline Number & Variable & $\begin{array}{c}\text { Average } \\
\text { Variance } \\
\text { Extracted } \\
\text { (AVE) }\end{array}$ & $\begin{array}{c}\text { AVE } \\
\text { Value } \\
\text { square of }\end{array}$ & $\begin{array}{c}\text { Value the } \\
\text { correlation with } \\
\text { TQM }\end{array}$ & $\begin{array}{c}\text { Rated relationship } \\
\text { with organizational } \\
\text { development }\end{array}$ \\
\hline 1 & SQ & 0.524 & 0.724 & 0.288 & 0.368 \\
2 & OC & 0.583 & 0.763 & 0.322 & \\
3 & EL & 0.485 & 0.696 & & \\
4 & TQM & 0.658 & 0.811 & & \\
5 & OD & 0.555 & 0.745 & & \\
\hline
\end{tabular}

Table 3 explains The square root value of the AVE exogenous construct service quality, organizational commitment, and educational leadership is higher than the value of the TQM 
correlation and organizational development; the exogenous construct indicators studied are entirely different and have met the criteria of discriminant validity shown in table. 4 .

Table 4. Summary of Revisions Index Structural Model Suitability

\begin{tabular}{lrll}
\hline Model Suitability Index & $\begin{array}{l}\text { Amos } \\
\text { Output }\end{array}$ & $\begin{array}{l}\text { Cut-Off } \\
\text { Value }\end{array}$ & Description \\
\hline Chi-squared $(\chi 2)$ & 237.57 & $<284.81$ & Good \\
Significance Probability & 0.139 & $>0.05$ & Good \\
CMIN / DF & 1.105 & $\leq 2.0$ & Good \\
GFI & 0.922 & $>0.90$ & Good \\
AGFI & 0.9 & $>0.90$ & Good \\
TLI & 0.987 & $>0.95$ & Good \\
CFI & 0.989 & $>0.95$ & Good \\
RMSEA & 0.021 & $\leq 0.08$ & Good \\
HOELTRE cN 0.01 & 256 & $>200$ & Good \\
\hline
\end{tabular}

Table 4 explains Chi-Squared $\left(\chi^{2}\right)$ 237.567. Threshold (cut-off value) Chi-Squared on the degree of significance of 0.05 and 244 free is 284.81 . In other words, $\chi 2$ full models are lower than the value of Cut of value. There is no difference between these two models. Significance probability is 0.139 . While the value of the Cut of value for significance probability is $\geq 0.05$. Ho is not enough evidence to exclude Ho, which means that there is no difference between the variance/covariance matrix and the variance/covariance matrix of the population. CMIN / DF is 1.105 , the comparison of CMIN / DF value is Cut of value $\leq 2.0$. Then this research model is fit following the recommended cut of value less than or equal to 2.0. GFI is 0.922 where it is still above Cut of value 0.90 but still on the level of fit. AGFI is 0.900 ; the recommended value is AGFI $\geq 0.90$. Produce marginal values, so the model matches within the marginal limit. TLI is 0.987 ; the recommended acceptance value is TLI $\geq 0.95$. CFI is 0.989 ; the recommended receipt value is CFI $\geq 0.95$. RMSEA is 0.021 , RMSEA value $\leq 0.08$ indicates a good index to accept the suitability of the model. The results of the analysis are obtained so that the model can be said to be fit or good shown in table. 5 .

Table 5. Full Weight Structural Regression model revised

\begin{tabular}{cccccccc}
\hline \multicolumn{2}{c}{ Regression Weight } & $\begin{array}{c}\text { Ustd } \\
\text { Estimate }\end{array}$ & $\begin{array}{c}\text { Std } \\
\text { Estimate }\end{array}$ & S.E. & C.R. & P \\
\hline TQM & $\leftarrow$ & SQ & 0.202 & 0.209 & 0.070 & 2.871 & 0.004 \\
TQM & $\leftarrow$ & OC & 0.326 & 0.227 & 0.110 & 2.966 & 0.003 \\
TQM & $\leftarrow$ & EL & 0.296 & 0.213 & 0.108 & 2.737 & 0.006 \\
OD & $\leftarrow$ & SQ & 0.159 & 0.225 & 0.050 & 3.149 & 0.002 \\
OD & $\leftarrow$ & OC & 0.249 & 0.236 & 0.079 & 3.156 & 0.002 \\
OD & $\leftarrow$ & EL & 0.262 & 0.258 & 0.077 & 3.396 & $* * *$ \\
OD & $\leftarrow$ & TQM & 0.163 & 0.223 & 0.058 & 2.805 & 0.005 \\
\hline
\end{tabular}

Table 5 shows values have met the hypothesis acceptance requirements, namely CR $>1.96$ at the significance level $\alpha=0.05$, it can be concluded that the results of SEM analysis of the empirical model of all proposed hypotheses related to the determinants of the development of SMP organizations in Pekalongan are significant (proven ) and received at a $95 \%$ confidence level. 
Results of research Service quality contributes positively to TQM following the research of [12]. Research on the integration of transformational leadership has a positive and significant effect on organizational development [13]. Corporate culture, educational leadership, government policy, adoption of innovation, and service quality have a significant influence on organizational change and development [14]. Other research the role of TQM has a positive correlation and has a significant effect on the change and organizational development of Taif University [15].

The acceptance of the seven hypotheses confirms that the development of a junior high school organization in Pekalongan is something new and must be done by all members of the organization through the implementation of good TQM. There needs to be further research that reveals the influence determinants of organizational development.

\section{Conclusion}

TQM-based junior high school organizational development determinants in Pekalongan are known that the variable influence of organizational commitment on TQM is the most dominant influence of exogenous variables but overall has a positive and significant effect. The impact of service quality on organizational development is positive and significant. Positive influence indicates that if there is a change in the implementation of TQM, there will be a change in the development of the organization of junior high schools in Pekalongan the same direction. 


\section{References}

[1] M. Lust, C. Huber, and J. Junne, "Academic Identity as a Discursive Resource for Resistance: The Case of Quality Management in German Higher Education Institutions. Springer, 32 (1), pp 49-69.," Springer, vol. 32, no. 1, pp. 49-69, 2018.

[2] J. Sitthisomjin, K. Somprach, and S. Phuseeorn, "The effects of innovation management on school performance of secondary schools in Thailand.," Kasetsart J. Soc. Sci., pp. 2-7, 2018.

[3] S. Srima, P. Wannapiroon, and P. Nilsook, "Design of Total Quality Management Information System (TQMIS) for Model School on Best Practice," Procedia - Soc. Behav. Sci., vol. 174, pp. 2160-2165, 2015.

[4] N. Ainna, S. E. Paramono, and Subagyo, "Pengaruh Kualitas Layanan, Citra Sekolah, dan Kepuasan Siwa Terhadap Loyalitas Siswa Islam Sudirman 2 Ambarawa,” J. Unnes Educ. Manag., vol. 5, no. 2, pp. 156-162, 2016.

[5] H. Yeh and D. Hong, "The Mediating Effect of Organizational Commitment on Leadership Type and Job Performance," J. Hum. Resour. Adult Learn., vol. 8, no. 2, pp. 50-59, 2012.

[6] Sikora, M. Z, and K. B., "The Process of Education of OSH Services and Organization Development. Human Resource Development Association, University of Lodz, Poland," Springer, vol. 18, pp. 321-330, 2012.

[7] A. Suktragool, K. Somtrakool, and P. Thidpad, "Cultural Aspect Management Model for Organization Development of Naval Education Department of the Royal Thai Navy," Can. Cent. Sci. Educ. Asian Cult. Hist., vol. 6, no. 2, pp. 163-170, 2014.

[8] R. T. B. Ardi and K. Sudarma, "Pengaruh Persepsi Dukungan dan Keadilan Organisasi Terhadap Organizational Citizenship Behavior Dengan Komitmen Organisasional Sebagai Variabel Intervening,” J. Unnes Manag. Anal., vol. 4, no. 2, pp. 142-152, 2015.

[9] A. Z. Acar, "Organizational Culture, Leadership Styles and Organizational Commitment in Turkish Logistics Industry,” Procedia - Soc. Behav. Sci., vol. 58, pp. 217-226, 2012.

[10] D. N. Anggarini, "Kontribusi Kepemimpinan Kepala Sekolah, Budaya Organisasi Dan Implementasi Manajemen Berbasis Sekolah Terhadap Mutu SMP Negeri Di Kabupaten Pemalang," J. Unnes Educ. Manag., vol. 3, no. 1, pp. 24-31, 2014.

[11] I. Keskes, "Relationship between leadership styles and dimensions of employee organizational commitment: A critical review and discussion of future directions," Omniascience Intang. Cap., vol. 10, no. 1, pp. 26-51, 2014.

[12] H. S. Sabet, Z. S. Saleki, B. Roumi, and A. Dezfoulian, “A Study on Total Quality Management in Higher Education Industry in Malaysia," vol. 3, no. 17, pp. 208-215, 2012.

[13] D. D. Warrick, "The Urgent Need for Skilled Transformational Leaders: Integrating Transformational Leadership and Organization Development,” J. Leadership, Account. Ethics vol., vol. 8, no. 5, pp. 11-26, 2011.

[14] U. A. H. Kahar, "Model Respon terhadap Perubahan dan Pengembangan Organisasi UIN Sunan Kalijaga Yogyakarta. Universitas Negeri Semarang," in proceeding, 2010.

[15] A. B. Alnaweigah, "Total Quality Management Role in Organizational Change and Development - Case Study: Taif University,” Int. J. Bus. Adm., vol. 4, no. 4, pp. 55-67, 2013. 